\title{
Biocidal Polymers (I): Preparation and biological activity of some novel biocidal polymers based on Uramil and its Azo-dyes
}

\author{
A.E.I. Ahmed ${ }^{\text {a, }}$, J.N. Hay ${ }^{\text {a }}$, M.E. Bushell ${ }^{\text {b }}$, J.N. Wardell ${ }^{\text {b }}$, G. Cavalli ${ }^{\text {a }}$ \\ ${ }^{a}$ Materials Chemistry Group, SBMS, University of Surrey, Guildford, Surrey, UK. GU2 7XH \\ ${ }^{b}$ Microbial Products Group, SBMS, University of Surrey, Guildford, Surrey, UK. GU2 7XH \\ * Corresponding author. Address: Chemistry, SBMS, Surrey University, Guildford, Surrey, UK. GU2 \\ 7XH. Tel/(0044)7999583570.E-mail address: $\underline{\text { a.i.ahmed@surrey.ac.uk }}$
}

\begin{abstract}
Biocidal polymers were prepared by reacting uramil with polyacrylonitrile and polyethylacrylate, and also by co-polymerizing heterocyclic monomers based on uramil azo-dyes with tolylene-2,6-diisocyanate and toluene-2,4-diisocyanate. The prepared polymers were converted to their quaternary salts and $\mathrm{N}$-halamine forms. Prepared N-halamine polymers were designed to contain multi available positions for halogenation and quaternarization and to tune the stability of halogens attached to the polymers. Antimicrobial activity of the prepared polymers against examples of Grampositive and Gram-negative bacteria was examined.
\end{abstract}

Key words: biocidal polymers; uramil; azo-dye; antimicrobial; N-halamine.

\section{Introduction}

A biocidal polymer is a polymer with the ability to kill microorganisms, by acting as a source of sterilizing ions or molecules. Four types of biocidal polymers have been described; polymers containing quaternary nitrogen atoms (poly-quats) (scheme 1, a) $[1,2]$, polymers containing phosphonium salts (polymeric phosphonium materials) (scheme 1, b) [3-12], polymers containing halogenated sulphonamide groups [halogenated poly(styrene-co-divinylbenzene)sulphonamide polymers] (scheme 1, c) $[13,14]$ and N-halamine polymers (scheme 1, d) [15-25]. Some poly-quats and polymeric phosphonium materials are water-soluble. As such, they are unsuitable for drinking water sterilization since they can adversely affect human health. They can be modified to be water-insoluble by converting them to the cross-linked form or by increasing their molecular weight and used as emulsions or suspensions in water. The mode of action of the these two types of biocidal polymers depend on surface 
adsorption, the polymer carries positive charges and bacteria at physiological $\mathrm{pH}$ carry a negative charge, resulting in cells being adsorbed. The poly-cations diffuse through the cell wall to bind to the cytoplasmic membrane resulting in disruption; releasing $\mathrm{K}^{+}$ions and the constituents of the cytoplasmic membrane resulting in cell death [26]. Most halogenated sulphonamide polymers are water-insoluble and their antibacterial action depends on the halogen exchange between the polymer and the bacterial cell, disturbing protein metabolism and causing cell death [13, 14].

The N-Halamine biocidal polymers described in the literature are water-insoluble; therefore they can be used safely in sterilizing drinking water and many other applications, such as disinfecting water supplies, swimming pools, hot-tubs, industrial water systems, and other applications where a sanitized water supply is required [1525]. N-Halamine biocidal polymers have been prepared previously by introducing five or six membered heterocyclic rings containing amide or imide functional groups to be halogenated (Scheme 1, d) [15-25]. The mode of action of N-halamine biocidal polymers, it has been suggested, depends on contact between the polymer and the bacteria which results in halogen exchange, killing the bacteria. N-halamine biocidal polymers are very stable, do not decompose in water to form toxic products, or release halogen until contact with the bacteria occurs [27].

In this work, uramil (1) not previously exploited in biocidal polymers, was introduced on polymers (polyacrylonitrile or polyethylacrylate) (See also Scheme 7). In addition, novel monomers containing this heterocyclic system were prepared which co-polymerized with other simple monomers such as tolylene-2,6-diisocyanate and toluene-2,4-diisocyanate. These polymers were modified in two ways: first, by converting the polymer to its quaternary salt, which confers limited water solubility, resulting in effective biological activity (poly-quats) [28, 30]; the second method was halogenating the polymers to convert them to the N-halamine form which are completely water insoluble [15-25]. The prepared polymers were designed to contain more available positions for halogenation and quaternarization than described for $\mathrm{N}$ halamine polymers in the literature. In addition, the uramil structure also aids stabilization of the halogens on the polymer. Prepared polymers (the modified) were tested for bactericidal activity against representative Gram-positive (Staphylococcus aureus) and Gram-negative (Escherichia coli) bacteria. The unmodified polymers were insoluble in water and their activity was measured as controls. In addition, the biological activity of the unmodified polymers saturated in DMSO, as they are 
completely insoluble is water and most of organic solvent, was also evaluated as potential disinfectants, antibiotics and antifouling agents.

\section{Experimental}

\subsection{Materials}

Barbituric acid, granulated tin, resorcinol, $m$-phenelenediamine, fuming nitric acid, sodium nitrite, polyacrylonitrile (average $M_{w}$ 150,000), polyethylacrylate (average $M_{w}$ 95,000), toluene-2,4-diisocyanate, tolylene-2,6-diisocyanate, bromine and iodine were supplied by Sigma Aldrich Chemicals, UK. Sodium hydroxide, hydrochloric acid, potassium permanganate, absolute ethanol, sulphuric acid, starch, sodium thiosulfate, potassium iodide, dimethylformamide (99.99\%) and methanol (analytical grade reagents) were supplied by Fisher Chemicals, UK.

\subsection{Preparation of polymers}

\subsubsection{Preparation of poly(N-iminouramil)ethylene (2) (series 1$)$}

Polyacrylonitrile $(0.50 \mathrm{~g}, 0.01 \mathrm{~mol})$ and uramil (5-aminobarbituric acid) (1) (1.4 g, $0.01 \mathrm{~mol}$ ) (prepared as described in the literature [29]) were heated in $30 \mathrm{ml}$ of dimethylformamide/absolute ethanol $(2: 1, \mathrm{v}: \mathrm{v})$ at $120^{\circ} \mathrm{C}$ in the presence of sodium hydroxide $(0.40 \mathrm{~g}, 0.01 \mathrm{~mol})$ for 48 hours. The reaction mixture was cooled and added gradually to a flask containing $50 \mathrm{~g}$ ice and the $\mathrm{pH}$ adjusted to $7 \mathrm{using} 0.1 \mathrm{M} \mathrm{HCl}$. The reddish brown solid product was filtered, dried and weighed, which produced $1.5 \mathrm{~g}$ (73\% yield), Scheme (7).

Analysis, FT-IR (KBr): $v_{\max }\left(\mathrm{cm}^{-1}\right) 1603(\mathrm{C}=\mathrm{O}$, imide), $1690(\mathrm{C}=\mathrm{O}$, amide), 1498 $(\mathrm{C}=\mathrm{N}), 1218(\mathrm{C}-\mathrm{N}), 3200\left(\mathrm{~N}-\mathrm{H}\right.$, imide) and 3421 (N-H amine). ${ }^{1} \mathrm{H}$ NMR (DMSO, $500 \mathrm{MHz}$ ): $\delta 2.04$ (b.s, 2H, $\mathrm{CH}_{2}$ ), 2.9 (s, 2H, $\mathrm{NH}_{2}$ ), 2.1 (b.s, 1H, CH), 3.2 (s, 2H, $2 \mathrm{NH}$ imides), and 7.9 (s, 1H, ring $\mathrm{CH}) .{ }^{13} \mathrm{C}$ NMR (DMSO, $125 \mathrm{MHz}$ ); ppm $28.6(\mathrm{CH}), 28.3$ $\left(\mathrm{CH}_{2}\right), 33.5(\mathrm{CH}$, ring $), 36.4(\mathrm{C}-\mathrm{N}), 121(\mathrm{C}=\mathrm{O}$, amide $)$ and $163(\mathrm{C}=\mathrm{O}$, imide) Elemental analysis, found (\%): C, 42.0; $\mathrm{H}, 4.1 ; \mathrm{N}$ 27.8. Calc. for $\mathrm{C}_{7} \mathrm{H}_{8} \mathrm{~N}_{4} \mathrm{O}_{3}$ (\%): $\mathrm{C}$, 42.9; H, 4.1; N, 28.6.

The same reaction was performed using polyethylacrylate $(1.0 \mathrm{~g}, 0.01 \mathrm{~mol})$ instead of polyacrylonitrile to prepare 5-polyacrylamidobarbituric acid (7) (series 2) and the final red solid product was filtered, dried and weighed, which produced $1.2 \mathrm{~g}(61 \%$ yield), Scheme (8). 
Analysis, FT-IR (KBr): $v_{\max }\left(\mathrm{cm}^{-1}\right) 1625(\mathrm{C}=\mathrm{O}$, no. 2), $1690(\mathrm{C}=\mathrm{O}$, amide, d), 1666 and 1680 (2C=O amide no. 3 and no. 1 respectively), 3113 ( $\mathrm{NH}$, imide) and 3447 (NH, amide) (scheme 2). ${ }^{1} \mathrm{H}$ NMR (DMSO, $500 \mathrm{MHz}$ ): $\delta 1.2$ (b.s, $2 \mathrm{H}, \mathrm{CH}_{2}$ ), 1.5 (b.s, 1H, CH), 5.4 (s, 1H, no 1), 7.1 (s, 1H, no. 2), 10.4 (s, 1H, no. 3) and 4.1 (s, 1H, no. 4) (scheme 2). ${ }^{13} \mathrm{C}$ NMR (DMSO, $\left.125 \mathrm{MHz}\right)$ : ppm $13.8\left(\mathrm{CH}_{2}\right), 28(\mathrm{CH}), 118$ (ring $\mathrm{CH}), 150(\mathrm{C}=\mathrm{O}, \mathrm{d}), 163(\mathrm{C}=\mathrm{O}, \mathrm{a}), 164.9(\mathrm{C}=\mathrm{O}, \mathrm{b})$ and $172(\mathrm{C}=\mathrm{O}, \mathrm{c}),($ Scheme 2). Elemental analysis, found (\%): $\mathrm{C}, 42.4 ; \mathrm{H}, 21.4 ; \mathrm{N}, 3.3$. Calc. for $\mathrm{C}_{7} \mathrm{H}_{7} \mathrm{~N}_{3} \mathrm{O}_{4}(\%)$ : C, 42.6; H, 21.5; N, 3.6.

\subsubsection{Diazotization of uramil}

Uramil (1.40 g, $0.01 \mathrm{~mol})$ was dissolved in $5 \mathrm{ml}$ concentrated sulphuric acid. The temperature was kept at $0^{\circ} \mathrm{C}$ using an external ice bath. A cold solution of $\mathrm{NaNO}_{2}$ $\left[0.69 \mathrm{~g}\right.$ of $\mathrm{NaNO}_{2}(0.01 \mathrm{~mol})+10 \mathrm{ml}$ water] was added drop wise to the uramil solution with stirring to form the uramildiazonium salt (12), Scheme (9).

\subsubsection{Preparation of 1,3-diamino-4-azo(5-barbituric acid)benzene (13)}

$m$-Phenylenediamine $(1.1 \mathrm{~g}, 0.01 \mathrm{~mol})$ and sodium hydroxide $(2.8 \mathrm{~g}, 0.07 \mathrm{~mol})$ were dissolved in $10 \mathrm{ml}$ water. The temperature was kept at $0^{\circ} \mathrm{C}$ using an external ice bath. This cold solution was added gradually to the uramildiazonium salt (12) with stirring. The resulting deep red solid product was filtered, dried and weighed, which produced $2.4 \mathrm{~g}$ (90\% yield), Scheme (9).

Analysis, FT-IR (KBr): $v_{\max }\left(\mathrm{cm}^{-1}\right) 3330\left(\mathrm{NH}\right.$, imide), $3392\left(\mathrm{NH}, \mathrm{NH}_{2}\right.$ near azo group), $3429\left(\mathrm{NH}, \mathrm{NH}_{2}\right.$ group away azo group), $1603(\mathrm{C}=\mathrm{O}$, imide), $1680(\mathrm{C}=\mathrm{O}$ amide), 2942 (CH aliphatic) and $1411(\mathrm{~N}=\mathrm{N}) .{ }^{1} \mathrm{H}$ NMR (DMSO, $\left.500 \mathrm{MHz}\right): \delta 5.4$ (s, $2 \mathrm{H}, \mathrm{NH}_{2}$ away azo group), 1.4 (s, 2H, $\mathrm{NH}_{2}$ near azo group), 6.1 (s, 2H, 2NH imide), 10.3 (s, 1H, ring $\mathrm{CH}$ ) and 6.9-7.5 (m, 3H, benzene ring). ${ }^{13} \mathrm{C}$ NMR (DMSO, 125 $\mathrm{MHz})$ : ppm 31 (ring $\mathrm{CH}), 175.9(\mathrm{C}=\mathrm{O}$, amide), $220(\mathrm{C}=\mathrm{O}$, imide) and 96.8, 107.8, 116.9, 124.5, 145 and 150 (aromatic). Elemental analysis, found (\%): C, 45.1; H, 3.6; $\mathrm{N}$, 32.9. Calc. for $\mathrm{C}_{10} \mathrm{H}_{10} \mathrm{~N}_{6} \mathrm{O}_{3}(\%)$ : C, 45.8; $\mathrm{H}, 3.8 ; \mathrm{N}, 33.1$.

\subsubsection{Preparation of poly[1,3-diamino-4(5-azobarbituric acid)benzene)-co- (tolylene-2,6-diisocyanate)] (poly-urea) (14) (series 3)}

Monomer (13) (2.6 g, $0.01 \mathrm{~mol})$ and tolylene-2,6-diisocyanate $(1.7 \mathrm{~g}, 0.01 \mathrm{~mol})$ were heated in $30 \mathrm{ml}$ dimethylformamide at $90^{\circ} \mathrm{C}$ for 5 hours. The reaction mixture was cooled and $50 \mathrm{ml}$ of methanol was added. The brown product was filtered, washed copiously with methanol, dried and weighed, which produced $4.1 \mathrm{~g}$ (93\% yield), Scheme (10). 
Analysis, FT-IR (KBr): $v_{\max }\left(\mathrm{cm}^{-1}\right) 1639(\mathrm{C}=\mathrm{O}$, imide $), 1680(\mathrm{C}=\mathrm{O}$, amide $), 3436$ (N-H, broad band), $1118(\mathrm{C}-\mathrm{N})$ and $1472(\mathrm{~N}=\mathrm{N}) .{ }^{1} \mathrm{H}$ NMR (DMSO, $\left.500 \mathrm{MHz}\right): \delta 2.2$ (s, 3H, $\mathrm{CH}_{3}$ ), 4.2 (s, 1H, NH, no.1), 5.9 (s, 1H, NH, no. 3), 4.8 (s, 1H, NH, no. 2), 6.7 (s, 2H, 2NH imide), 7-8.3 (m, 6H, aromatic), $6.5(\mathrm{~s}, 1 \mathrm{H}, \mathrm{NH}$, no.4) and $9.2(\mathrm{~s}, 1 \mathrm{H}$, heterocyclic ring $\mathrm{CH}$ ) (Scheme 3). ${ }^{13} \mathrm{C}$ NMR (DMSO, $125 \mathrm{MHz}$ ): ppm $12.4\left(\mathrm{CH}_{3}\right), 49$ (heterocyclic ring $\mathrm{CH}$ ), 100.3, 110, 111.3, 111.7, 113, 118, 121, 123, 125, 137, 144 and 146 (aromatic), $162(\mathrm{C}=\mathrm{O}$, imide), $152(\mathrm{C}=\mathrm{O}, \mathrm{a}), 153(\mathrm{C}=\mathrm{O}, \mathrm{b})$ and $174(\mathrm{C}=\mathrm{O}$, heterocyclic ring amide) (Scheme 3). Elemental analysis, found (\%): C, 52.1; H, 3.5; $\mathrm{N}$, 24.8. Calc. for $\mathrm{C}_{19} \mathrm{H}_{16} \mathrm{~N}_{8} \mathrm{O}_{5}(\%)$ : C, 52.3; H, 3.6; N, 25.7.

The same reaction was performed using toluene-2,4-diisocyanate to prepare poly[1,3-diamino-4(5-azobarbituric acid)benzene)-co-(tolulene-2,4-diisocyanate)] (poly-urea) (19) (series 4).

Analysis, FT-IR (KBr): $v_{\max }\left(\mathrm{cm}^{-1}\right) 1609(\mathrm{C}=\mathrm{O}$, imide), $1650(\mathrm{C}=\mathrm{O}$, amide $), 3446$ (N-H, broad band), $1136(\mathrm{C}-\mathrm{N})$ and $1547(\mathrm{~N}=\mathrm{N}) .{ }^{1} \mathrm{H}$ NMR (DMSO, $\left.500 \mathrm{MHz}\right): \delta 2.1$ (s, 3H, $\mathrm{CH}_{3}$ ), 4.8 (s, 1H, NH, no.1), 6.7 (s, 1H, NH, no. 3), 7.0 (s, 1H, NH, no. 2), 7.3 (s, 2H, 2NH imide), 7.9-8.8 (m, 6H, aromatic), 7.7 (s, 1H, NH, no.4) and 9.1 (s, 1H, heterocyclic ring $\mathrm{CH}$ ) (Scheme 4). Elemental analysis, found (\%): C, 52.2; H, 3.4; N, 24.9. Calc. for $\mathrm{C}_{19} \mathrm{H}_{16} \mathrm{~N}_{8} \mathrm{O}_{5}(\%)$ : C, 52.3; H, 3.6; N, 25.7.

\subsubsection{Preparation of 1,3-dihydroxy-4(5-azobarbituric acid)-benzene (24)}

Resorcinol (1.1 g, $0.01 \mathrm{~mol})$ and $\mathrm{NaOH}(5.5 \mathrm{~g}, 0.14 \mathrm{~mol})$ were dissolved in $20 \mathrm{ml}$ water and added gradually to cold uramildiazonum salt (12). The dark purple product was filtered, washed copiously with cold water, dried and weighed, which produced 2.6 g (99\% yield), Scheme (9).

Analysis, FT-IR (KBr): $v_{\max }\left(\mathrm{cm}^{-1}\right) 1603(\mathrm{C}=\mathrm{O}$, imide), $1705(\mathrm{C}=\mathrm{O}$, amide), 1411 $(\mathrm{N}=\mathrm{N}), 3100(\mathrm{~N}-\mathrm{H}), 3432(\mathrm{OH})$ and $2942\left(\mathrm{CH}\right.$ aliphatic). ${ }^{1} \mathrm{H}$ NMR (DMSO, 500 $\mathrm{MHz}): \delta 1.3$ (s, 1H, OH near azo group), 5.4 (s, 1H, OH away azo group), 6.2 (s, 2H, $2 \mathrm{NH}$ imides), 6.9-7.2 (s, 3H, aromatic) and $10.2(\mathrm{~s}, 1 \mathrm{H}$, heterocyclic ring $\mathrm{CH}) .{ }^{13} \mathrm{C}$ NMR (DMSO, $125 \mathrm{MHz}$ ): ppm 49 (heterocyclic ring CH), 102.4, 103, 105, 106, 129 and 150.3 (aromatic), $158.3(\mathrm{C}=\mathrm{O}$, amide) and $(\mathrm{C}=\mathrm{O}$, imide). Elemental analysis, found (\%): C, 45.1; H, 2.9; N, 20.9. Calc. for $\mathrm{C}_{10} \mathrm{H}_{8} \mathrm{~N}_{4} \mathrm{O}_{5}(\%)$ : C, 45.5; H, 3; N, 21.2.

2.2.6. Preparation of poly[(1,3-dihydroxy-4(5-azobarbituric acid)-benzene)-co(tolylene-2,6-diisocyanate)] (polyurethane) (25) (series 5)

Monomer (24) (2.6 g, $0.01 \mathrm{~mol})$ and tolylene-2,6-diisocyanate $(1.7 \mathrm{~g}, 0.01 \mathrm{~mol})$ were heated in $30 \mathrm{ml}$ dimethylformamide for 5 hours at $90^{\circ} \mathrm{C}$. The reaction was 
cooled and $50 \mathrm{ml}$ of methanol was added. The brown product was filtered, washed copiously with methanol, dried and weighed, which produced 3.8 g (86\% yield), Scheme (11).

Analysis, FT-IR (KBr): $v_{\max }\left(\mathrm{cm}^{-1}\right) 1640(\mathrm{C}=\mathrm{O}$, imide), $1700(\mathrm{C}=\mathrm{O}$, urethane group), $1660(\mathrm{C}=\mathrm{O}$, heterocyclic ring amide), $3429(\mathrm{~N}-\mathrm{H}), 1135$ (broad band for $\mathrm{C}-\mathrm{O}$ \& $\mathrm{C}-\mathrm{N}$ bonds), $1471(\mathrm{~N}=\mathrm{N})$ and $2920\left(\mathrm{CH}\right.$ aliphatic). ${ }^{1} \mathrm{H}$ NMR (DMSO, $\left.500 \mathrm{MHz}\right): \delta$ 2.2 (s, 3H, $\left.\mathrm{CH}_{3}\right), 4.8$ (s, 1H, NH no.1), 4.2 (s, 1H, NH no.2), 6.8 (s, 2H, 2NH imide), $10.5(\mathrm{~s}, 1 \mathrm{H}$, heterocyclic ring $\mathrm{CH})$ and 7.0-8.4 (s, 6H, benzene rings) (Scheme 5$).{ }^{13} \mathrm{C}$ NMR (DMSO, $125 \mathrm{MHz}$ ): ppm $11.4\left(\mathrm{CH}_{3}\right), 49$ (heterocyclic ring $\mathrm{CH}$ ), 109.9, 111.6, 113.2, $116117.9,118.5,120,121,125,137.3,137.7$ and 146 (aromatic), 150 (C=O, ring amide), $185(\mathrm{C}=\mathrm{O}$, imide), $163.0(\mathrm{C}=\mathrm{O}, \mathrm{b})$ and $153.2(\mathrm{C}=\mathrm{O}$, a) (Scheme 5). Elemental analysis, found (\%): C, 51.7; H, 3.2; N, 18.1. Calc. for $\mathrm{C}_{19} \mathrm{H}_{16} \mathrm{~N}_{8} \mathrm{O}_{7}(\%)$ : C, $52.1 ; \mathrm{H}, 3.2 ; \mathrm{N}, 19.2$.

The same reaction was performed using toluene-2,4-diisocyanate to prepare poly[1,3-dihydroxy-4(5-azobarbituric acid)benzene)-co-(tolulene-2,4-diisocyanate)] (polyurethane) (30) (series 6).

Analysis, FT-IR (KBr): $v_{\max }\left(\mathrm{cm}^{-1}\right) 1617(\mathrm{C}=\mathrm{O}$, imide), $1639(\mathrm{C}=\mathrm{O}$, amide), 1712 (C=O, urethane), $3417(\mathrm{~N}-\mathrm{H}$, imide), $3458(\mathrm{~N}-\mathrm{H}$, amide), $3550(\mathrm{OH}), 110(\mathrm{C}-\mathrm{N}$ \& CO) and $1457(\mathrm{~N}=\mathrm{N}) .{ }^{1} \mathrm{H}$ NMR (DMSO, $\left.500 \mathrm{MHz}\right): \delta 2.0\left(\mathrm{~s}, 3 \mathrm{H}, \mathrm{CH}_{3}\right), 6.4(\mathrm{~s}, 1 \mathrm{H}, \mathrm{NH}$, no.1), 7.1 (s, 1H, NH, no. 2), 6.9 (s, 2H, imide), 7.4-8.5 (m, 6H, aromatic), and 9.4 (s, $1 \mathrm{H}$, heterocyclic ring $\mathrm{CH}$ ) (scheme 6). ${ }^{13} \mathrm{C} \mathrm{NMR}$ (DMSO, $125 \mathrm{MHz}$ ): ppm $12\left(\mathrm{CH}_{3}\right)$, 49 (heterocyclic ring $\mathrm{CH}$ ), 106, 110, 113, 114, 115, 116, 119, 119.6, 120, 121, 123 and 126 (aromatic), $128(\mathrm{C}=\mathrm{O}$, ring amide), $151(\mathrm{C}=\mathrm{O}$, imide), $154(\mathrm{C}=\mathrm{O}, \mathrm{b})$ and 160 $(\mathrm{C}=\mathrm{O}$, a) (scheme 6). Elemental analysis, found (\%): $\mathrm{C}, 51.8 ; \mathrm{H}, 3.2 ; \mathrm{N}, 18.5$. Calc. for $\mathrm{C}_{19} \mathrm{H}_{16} \mathrm{~N}_{8} \mathrm{O}_{7}(\%)$ : C, 52.1; H, 3.2; N, 19.2.

All the prepared polymers are insoluble in water and most organic solvents. The non-modified polymers dissolve partially (less than 30\%) in DMSO by soaking for 310 days at $30-40^{\circ} \mathrm{C}$. The partially dissolved polymers were filtered to carry out the analysis. However, $\mathrm{M}_{\mathrm{w}}$ characterization was not possible due to the need to completely dissolve the material in low-viscosity solvents for GPC.

\subsubsection{Halogenation process}

The different types of the n-halamine polymers were halogenated by the same method: polymer was dispersed in sodium hydroxide solution and the halogen 
(chlorine, bromine or iodine) was added gradually until neutralization to $\mathrm{pH}$ 7. The mixture was stirred for a further hour during which the temperature was kept below $5^{\circ} \mathrm{C}$ using an external ice bath. The resulting product was filtered, washed copiously with chlorine free water, dried and weighed [31, 32]. The resulted polymers are completely water insoluble. The amounts of polymers and sodium hydroxide used in the preparation of each N-halamine polymer and the final yield are illustrated in Table 1.

The halogenation process was followed using IR spectroscopy [30-32] and the halogen/g content was determined using iodometric titration [24]. The values are given in Table 2.

\subsubsection{Quaternarization process}

The polymer was dispersed in water $(10 \mathrm{ml})$ and diluted $\mathrm{HCl}$ added. The temperature was kept below $10^{\circ} \mathrm{C}$ using an external ice/water bath and the mixture was stirred for 1 hour. The polymer salts were partially soluble in water $(20 \%$ maximum). Methanol $(50 \mathrm{ml})$ was then added to the solution to precipitate the dissolved polymer. The resulting product was filtered, washed copiously with methanol, dried and weighed [28, 30]. The amounts of polymers, and the volumes of $\mathrm{HCl}$ used are given in Table 3.

\subsection{Biological activity of the prepared polymers}

The prepared polymers were tested against both Gram-positive and Gram-negative bacteria as follows:

\subsubsection{Agar plate method}

Nutrient agar (Oxoid) was prepared $(250 \mathrm{ml})$, held molten at $50^{\circ} \mathrm{C}$ and $1.0 \mathrm{ml}$ of a 24hr nutrient broth culture of either Staphylococcus aureus or Escherichia coli was added as an inoculum. The seeded agar was poured into square assay plates ( $24 \times 24$ $\mathrm{cm}$ ); two plates for each type of bacterium, Gram-positive and Gram-negative bacteria. Thirty-six, $5 \mathrm{~mm}$ wells were cut into the agar according to a square pattern (chessboard). Small amounts of each polymer $(0.03 \mathrm{~g})$ were placed in a well in the middle of each square. The experiment was performed in replicate, three wells for each polymer. The plates were incubated for 24 hours at $37^{\circ} \mathrm{C}$ and the inhibition zones around the polymers were recorded. All the prepared polymers, including halogenated polymers and the quaternarized salts were examined for biocidal activity. The unmodified polymers were used as controls [28, 30-32]. 
The unmodified polymers $(\mathbf{2}, 7, \mathbf{1 4}, \mathbf{1 9}, \mathbf{2 5}$ and $\mathbf{3 0})$, as well as monomers (13 and 24) were examined in their partially soluble form by dissolving them in dimethylsulphoxide (DMSO) and the solvent was used as control. For each polymer $0.01 \mathrm{~g}$ was dissolved in $1 \mathrm{ml}$ DMSO (the samples were soaked in DMSO for more than 10 days) and $0.03 \mathrm{ml}$ from the prepared solution was added to the wells in the plates, the experiment was performed in replicate, three wells for each polymer.

\section{Results and Discussion}

N-halamine biocidal polymers have been used in sterilization technology for almost a decade [5-25]. To prepare this type of polymer a heterocyclic ring is introduced into the polymer backbone or side chain. The heterocyclic ring contains amide or imide function groups which can be halogenated [5-25]. In this work the heterocyclic polymers were prepared by reacting the ready-prepared 5aminobarbituric acid ring (1) (uramil) with a polymer (Schemes 7 and 8). Uramil contains three main positions available for halogenation which gave the opportunity to prepare multi-halogen biocidal polymers (MHBP). This increases the number of available halogens per monomer unit compared with existing $\mathrm{N}$-halamine polymers [5-25]. These positions can also be acidified to form poly-quats.

The positions in uramil available for halogenation are imides, rather than amides. Halogenated imide groups are considered to have potential as biocides as the imide group can easily release free halogen $[35,36]$. The dissociation constant for the imide halogen in trichlorocynuric acid for example is from $1.6 \times 10^{-12}$ to $8.5 \times 10^{-4}$, for amide halogen is $1.6 \times 10^{-8}$ in 1,3-dichloro-2,2,5,5-tetramethylimidazolidine-4-one and for amino halogen is $<10^{-12}$ for 1-chloro-2,2,5,5-tetramethylimidazolidine-4-one [35]. This indicates that the amine halamine bond is the most stable but results in a less bioactive polymer as halogen is not easily released in aqueous media [35]. The imide halogen exhibits the lowest stability but offers the best biological action while amide halogens have intermediate stability and moderate biological activity; enough for effecting sterilization $[35,36]$. The presence of the methyl groups on the heterocyclic rings in 1,3-dichloro-2,2,5,5-tetramethylimidazolidine-4-one and 3chloro-4,4-dimethyl-2-oxazolidinone increases the stability of the halogens attached to the polymer by increasing the electron density over the ring, and this makes the hydantion based polymers the best halamine biocidal polymers currently on the market [15-25]. We took this into consideration to design a new type of halamine 
polymer containing imide groups where the stability improved by increasing the electron density over the ring. In polymer (2) (scheme 7) prepared by reacting uramil with polyacrylonitrile; the resulting structure contains enamine groups in resonance with the ring. The resonance driven by the electron pairs of the amino group will result in increasing the electron density over the heterocyclic ring which was expected to stabilize the nitrogen-halogen bond, making the release of halogen more difficult. The same effect was expected with polymer (7) (scheme 8), in this case the $\mathrm{OH}$ group of the amidol form being the resonance driving force. The monomers $(\mathbf{1 3}, \mathbf{2 4})$ (scheme 9) were designed following a similar reasoning. In this case we expect that by coupling the heterocyclic ring over $m$-phenylenediamine or resorcinol good resonance, from the amino or hydroxyl groups through the aromatic ring and the azo group to the heterocyclic ring, increases the electron density over the heterocyclic ring. This results in increased stability of the halogen-nitrogen bond on the ring. After co-polymerization to form the poly-urea and polyurethane, the nitrogen and the oxygen lone electron pairs still have the ability to resonate with the heterocyclic ring creating stability.

Thus, by making use of uramil and the selected polymer backbones, we aimed to develop a new series of water insoluble N-halamine biocidal polymers, exhibiting a good balance of stability-biocidal activity and containing multi-available positions for halogenation (4 or more). N-halamine biocidal polymers currently available on the market depend on only one available position for halogenation based on hydantions systems [15-25]. Some previous examples of N-halamine biocidal polymers have been reported based on 2 and 3 available halogenation positions, using six membered heterocyclic rings, but the stability did not improve in these polymers over traditional halogenated hydantoins [28, 31-32].

Reacting uramil with polyacrylonitrile gave polymer (2) (scheme 7). IR characterisation indicated that the reaction had reached completion (disappearance of the cyano peak at $2240 \mathrm{~cm}^{-1}$ ). Using polyethylacrylate instead of polyacrylonitrile gave polymer (7) (scheme 8) also quantitatively, IR characterisation showed complete disappearance of ester carbonyl group peak at $1735 \mathrm{~cm}^{-1}$.

The halogenation of polymer (7) was a highly exothermic reaction, unlike the halogenation of (2). In spite of careful temperature control and slow addition of halogen to polymer (7) the halogenation yield was very low. A plausible explanation is that some amide bonds connecting the heterocyclic ring to the polymer were 
hydrolysed during halogenation. This is supported by IR data which shows the presence of carboxylic acid OH group in polymer (8) $\left(2423-3510 \mathrm{~cm}^{-1}\right)($ Scheme 8) and the low halogen content measured, compared with similar polymers (polymers 810, Table 2).

Monomers $(\mathbf{1 3}, \mathbf{2 4})$ (scheme 9) were prepared by coupling uramildiazonium salt with resorcinol and $m$-phenylenediamine. These monomers were considered as novel azo-dyes. These two monomers were co-polymerized with tolylene-2,6-diioscyanate and toluene-2,4-diisocyanate to form polyurethanes $(\mathbf{2 5}, \mathbf{3 0})$ and poly-ureas $(\mathbf{1 4}, \mathbf{1 9})$. In polyurethanes $(\mathbf{2 5}, \mathbf{3 0})$ there are 5 available positions for halogenation and in polyureas $(\mathbf{1 4}, \mathbf{1 9})$ there are 7 positions for halogenation. From the IR data the azo group peak appeared around $1411 \mathrm{~cm}^{-1}[33,34]$ in both of the two monomers (13 \& 24) (and in the resulting polymers) indicating that the coupling was successful. This method of preparation resulted in the development of MHBP with an even greater number of available halogens than polymers (2) and (7).

Tested against bacteria, including Gram-positive (Staphylococcus aureus) and Gram-negative bacteria (Escherichia coli), the polymers were divided into three categories: The first group is the polymer without any modification (water insoluble polymers) and this category includes polymers (2), (7), (14), (19), (25) and (30) that acted as controls. The second category contains the water insoluble $\mathrm{N}$-halamine biocidal polymers resulting from chlorination, bromination and iodination of the first category and this includes polymers (3), (4), (5), (8), (9), (10), (15), (16), (17), (26), (27), (28), (31), (32) and (33). The third category contains the quaternarized forms (has a limited water soluble amount), which resulted from acidification of the first group and this includes polymers (6), (11), (18), (23), (29) and (34). The polymers results from modifications to polymer (2), (7), (14), (19), (25) and (30) were considered as series 1, 2, 3, 4, 5 and 6 respectively (scheme 7-8, 10-11). Biological activity was tested by the agar plate method described earlier. Zones of inhibition of bacterial growth around each polymer were recorded after incubation at $37^{\circ} \mathrm{C}$ for 24 hours (Tables 4 and 5).

From tables 4 and 5, the controls (the original polymers without modification) did not show any biological activity; these polymers are not soluble in water and do not release any effective ion that can diffuse into the medium. The second category, $\mathrm{N}$ halamine biocidal polymers, showed significant inhibition zones. These polymers are also water-insoluble; implying their mode of action is the release into the medium of 
soluble halogen-containing ions that are lethal to the bacterial cells. The action of the third category (Poly-quats) depends on the solubility of the polymer itself. The conversion of the polymer to its quaternary salt increases its solubility (to a limited extent) so it can diffuse through the medium and exert its biocidal effect. Polymer (7) and its modified polymer (8) (chlorinated) did not show any bactericidal activity while the other modified forms of it showed low biological activity. This is may be due to the halogenation of this polymer being a highly exothermic reaction which resulted in hydrolysis of some heterocyclic rings leading to a decrease in its biological power. From tables 4 and 5 it was clear that the N-halamine polymers in series 3-6 show greater biological activity than series 1 and 2; perhaps because the number of available positions for the halogen in series 3-6 is greater than that in series 1 and 2, which is reflected in the amount of halogen loading on the polymer in table 2 . The biological activity of the quaternarized forms is similar; especially series 1 which becomes very similar to series $3-6$, and may be because the repeating unit molecular weight of the poly-quats in series 1 is very low compared to the available positions for acidification on its surface.

The control polymers (2), (7), (14), (19), (25) and (30) as well as the monomers (13 and 24), were also tested as bioactive materials by dissolving them in an organic solvent (they are dissolving partially in DMSO) and using this solvent as a control. The results are in table 6.

DMSO was used as the control and its inhibition zone diameter was $5 \mathrm{~mm}$ for both E. coli and S. aureus. The only exception is monomer (24) which was dissolved in water. From table 6 it was clear that all the prepared polymers and monomers show biological activity. This indicates a potential use for these polymers as antifouling agents and as antiseptics.

Pervious work suggest that $\mathrm{N}$-halamine biocidal polymers act by contact. $^{20-23}$ However, the results of our inhibition zone assays on water insoluble polymers indicates another mechanism, based on the release of active species. Further investigations into these polymers are being conducted to quantify the biological activity and determine the mode of action the results will be communicated in due course. Optimisation of conditions to achieve maximum halogenation of these novel biocidal polymers is also under investigation together with using uramil (1) to produce other novel monomers and polymers for use in different applications. 


\section{Conclusions}

Insoluble N-halamine polymers and partially soluble poly-quats biocidal polymers were prepared and their structures were determined using different spectroscopic techniques. These polymers have multi-available positions for halogenation and the halogen-nitrogen bond was stabilized by introducing electron donating groups on the heterocyclic ring to balance the stability and enhance the biological activity. Most of these novel polymers show high disinfecting power against different types of bacteria (Gram-positive and Gram-negative) especially the N-halamine polymers. The partially soluble forms of the control polymers and the soluble monomers also have potential as disinfecting agents.

\section{Acknowledgements}

This work is funded by the Egyptian Government (Ministry of Higher Education).

\section{References}

[1] G.L. Hatch, US Patent No. 4187183 (1980).

[2] G.L. Hatch, US Patent No. 4190529 (1980).

[3] A. Kanazawa, I. Ikeda, I. Endo, J. Polym. Sci. Part A: Polym. Chem. 31 (1993) 335.

[4] A. Kanazawa, I. Ikeda, I. Endo, J. Polym. Sci. Part A: Polym. Chem. 31 (1993) 1441.

[5] A. Kanazawa, I. Ikeda, I. Endo, J. Polym. Sci. Part A: Polym. Chem. 31 (1993) 1467.

[6] A. Kanazawa, I. Ikeda, I. Endo, J. Polym. Sci. Part A: Polym. Chem. 31 (1993) 3031.

[7] A. Kanazawa, I. Ikeda, I. Endo, J. Polym. Sci. Part A: Polym. Chem., 31 (1993) 3003.

[8] A. Kanazawa, I. Ikeda, I. Endo, J. Appl. Polym. Sci. 52 (1994) 641.

[9] A. Kanazawa, I. Ikeda, I. Endo, J. Appl. Polym. Sci. 53 (1994) 1237.

[10] A. Kanazawa, I. Ikeda, I. Endo, J. Appl. Polym. Sci. 53 (1994) 1245.

[11] A. Kanazawa, I. Ikeda, I. Endo, J. Appl. Polym. Sci. 54 (1994) 1305.

[12] A. Kanazawa, I. Ikeda, I. Endo, J. Polym. Sci. Part A: Polym. Chem. 32 (1994) 1992.

[13] D.W. Emerson, Ind. Eng. Chem. Res. 32 (1993) 1228. 
[14] D.W. Emerson, D.J Shea, E.M Sorenson, Ind. Eng. Chem. Res. 17 (1978) 269.

[15] G. Sun, W.B. Wheatly, S.D. Worley, Ind. Eng. Chem. Res. 33 (1994) 168.

[16] G. Sun, L.C. Allen, E.P. Luckie, W.B. Wheatly, S.D. Worley, Ind. Eng. Chem. Res. 34 (1994) 4106.

[17] G. Sun, T.Y. Chen, W.B. Wheatly, S.D. Worley, J. Bioact. Compat. Polym. 10 (1995) 135.

[18] G. Sun, T.Y. Chen, M.S. Habercom, W.B. Wheatly, S.D. Worley, J. Am Water Res. Assoc. 32 (1996) 793.

[19] V.S. Panangala, L. Liu, G. Sun, S.D. Worley, A. Mitra, J. Virol Meth. 66 (1997) 263.

[20] Y. Chen, S.D. Worley, J. Kim, C.-I Wei, T.Y. Chen, Ind. Eng. Chem. Res. 42 (2003) 280.

[21] Y Chen, S.D. Worley, J. Kim, C.-I Wei, J. Suess, Chem. Res. 42 (2003) 5715.

[22] Y Chen, S.D. Worley, T.S. Huang, J. Weese, J. Kim, C.-I Wei, J. Appl. Polym. Sci. 92 (2004) 363.

[23] Y Chen, S.D. Worley, T.S. Huang, J. Weese, J. kim, C.-I Wei, J. Appl. Polym. Sci. 92 (2004) 368.

[24] Z. Chen, Y. Sun, Ind. Eng. Chem. Res. 45 (2006) 2634.

[25] J. Liang, J. R. Owens, T. S. Huang, S. D. Worley, J. Appl. Polym. Sci. 101 (2006) 5 .

[26] T. Tashiro, Macromol. Mater. Eng. 286 (2001) 63.

[27] S.D. Worley, D.E. Williams, Crit. Rev. Environ. Cont. 18 (1988) 133.

[28] A.M. El-Masry, Pigment and Resin Tech. 34 (2005) 265.

[29] S.F Brian; J.H Antony, W.G.S Peter, R.T Austin, 'Vogel' text book of practical organic chemistry', Longman Ltd, Fifth edition (1989).

[30] H.Y. Moustafa, Pigment \& Resin Tech. 35 (2006) 71.

[31] A.M. El-Masry, H.Y. Moustafa, A.I. Ahmed, A.F. Shaaban, Pigment \& Resin Tech. 33 (2004) 75.

[32] A.M. El-Masry, H.Y. Moustafa, A.I. Ahmed, A.F. Shaaban, Pigment \& Resin Tech. 33 (2004) 211.

[33] R.H. Maradiya, S.V. Patel, J. Braz. Chem. Soc. 12 (2001) 710.

[34] A.S. Abd-El-Aziz, T.H. Afifi, Dyes and pigments 70 (2006) 8.

[35] K. Barnes, J. Liang, R. Wu, S.D. Worley, J. Lee, R.M. Broughton, T.S. Huang, Biomaterials 27 (2006) 4825. 
[36] Z. Chen, J. Luo, Y. Sun, Biomaterials, 28 (2007) 1597. 


(a)

Scheme 1. Structures of the different biocidal polymers. 


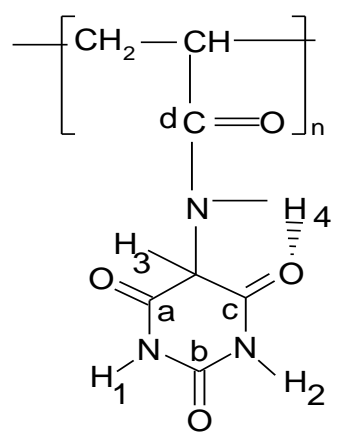

Scheme 2. Numbering the hydrogen and carbon atoms in 5-polyacrylamidobarbituric acid. 


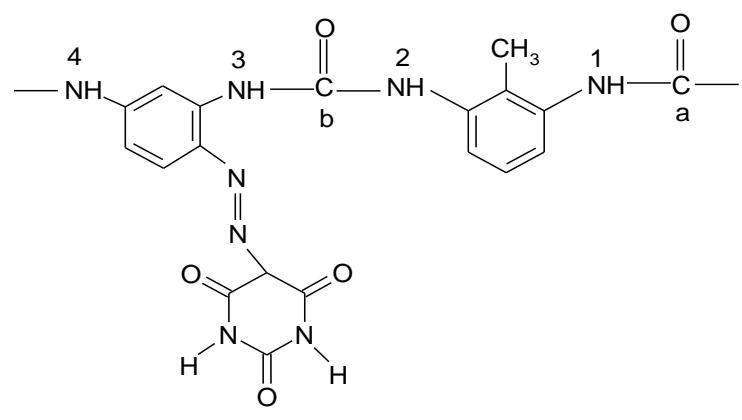

Scheme 3. Numbering the hydrogen and carbon atoms in poly-urea (14). 


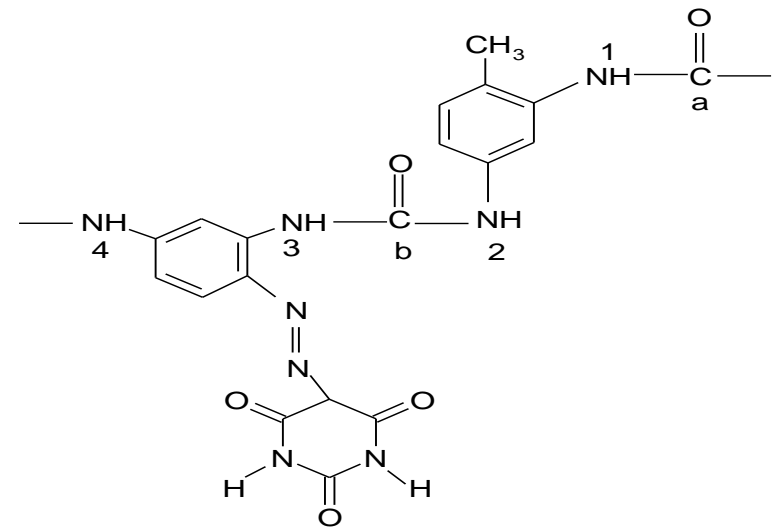

Scheme 4. Numbering the hydrogen and carbon atoms in poly-urea (19). 


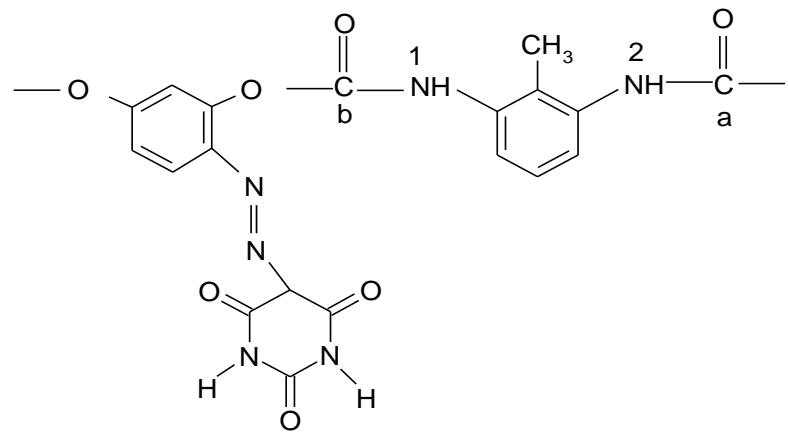

Scheme 5. Numbering the hydrogen and carbon atoms in polyurethane (25). 


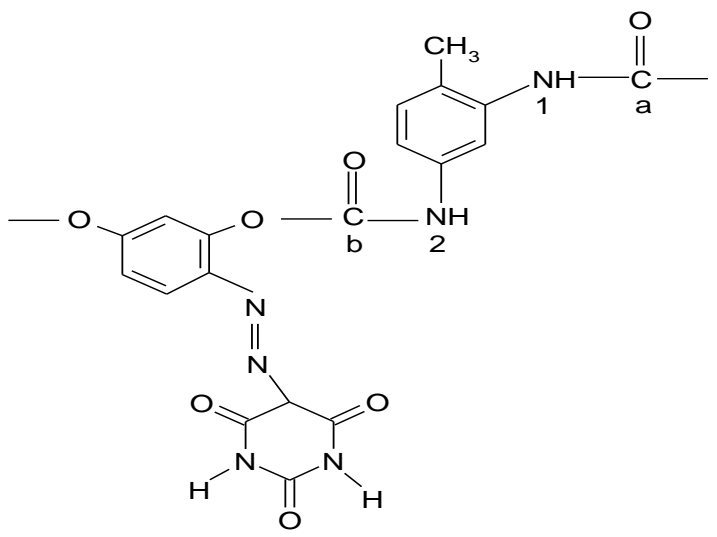

Scheme 6. Numbering the hydrogen and carbon atoms in polyurethane (30). 
<smiles>CC1CCCC1[O+]=C1NC(=O)C(N)C(=O)N1</smiles>

(1)

5-aminobarbituric acid

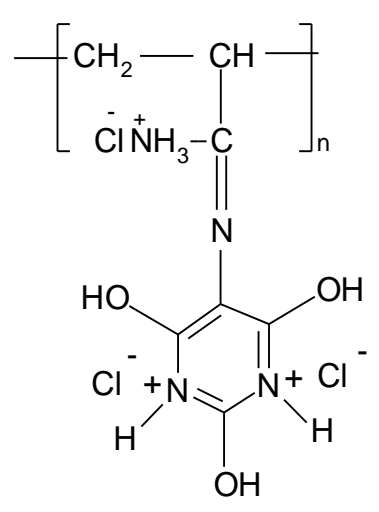

(6)<smiles>CCC(CC(C)CO[N+](=O)[O-])C(=N)N</smiles><smiles>NC1CNC(=O)NC1=O</smiles>

(2)

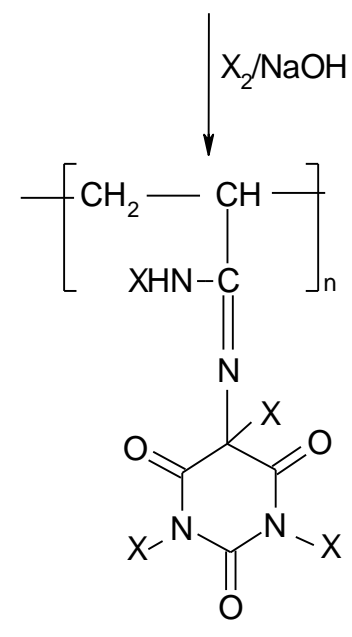

(3) $\mathrm{X}=\mathrm{Cl}$

(4) $\mathrm{X}=\mathrm{Br}$

(5) $X=1$

Scheme 7. Preparation of poly(N-iminouramil)ethylene and its halogenation and acidification, series 1 . 
<smiles>NC1NC(=O)C(=[OH+])NC1=O</smiles>

(1)<smiles>CCOC(=O)C(C)CC(C)C</smiles>

Polyethylacrylate

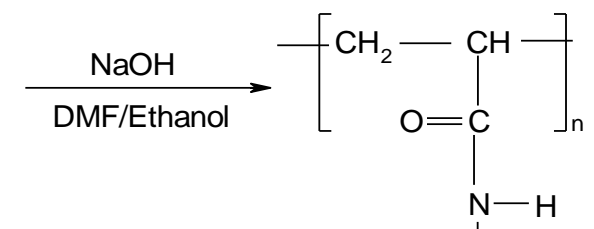<smiles>C=NC1C(=O)NC(=O)NC1=O</smiles>

(7)

5-aminobarbituric acid
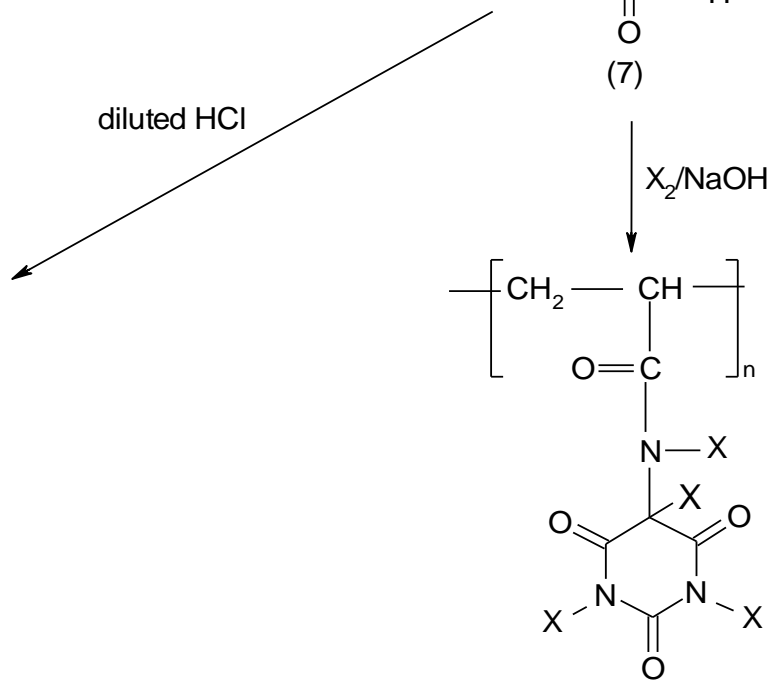

(11)

Scheme 8. Preparation of 5-polyacrylamidobarbituric acid and its halogenation and acidification, series 2 . 


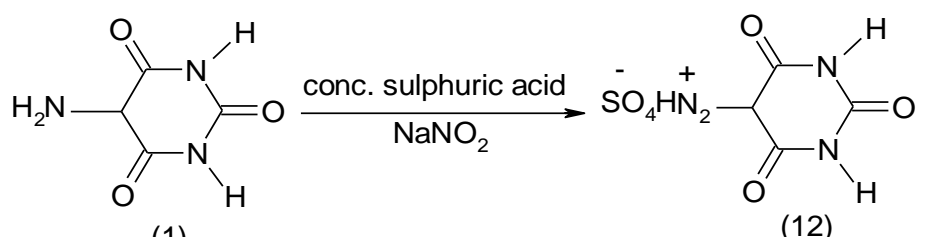

(1)

5-barbituric diazonium chloride

5-aminobarbituric acid

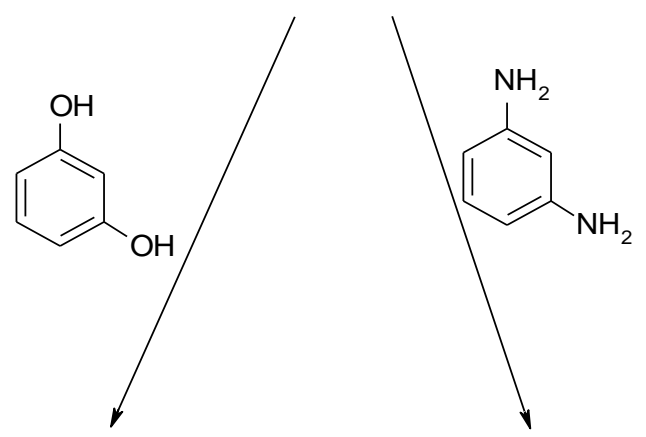<smiles>O=C1NC(=O)C(N=Nc2ccc(O)cc2O)C(=O)N1</smiles>

(24)<smiles>Nc1ccc(N=NC2C(=O)NC(=O)NC2=O)c(N)c1</smiles>

(13)

Scheme 9. Diazotization of uramil and its coupling with $m$-phenylenediamine and resorcinol. 


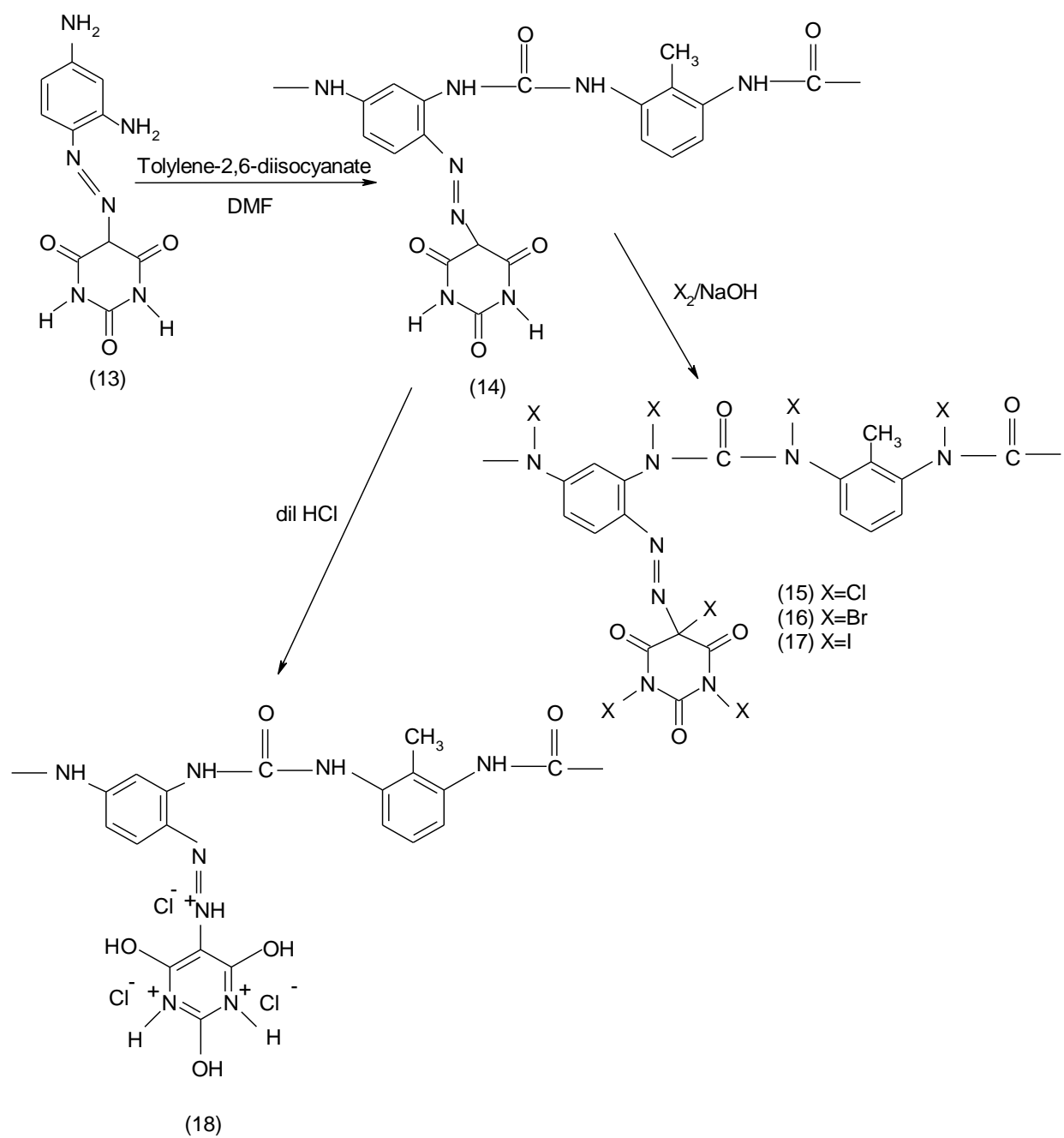

Scheme 10. Preparation of poly[1,3-diamino-4(5-azobarbituric acid)-benzene)-co(tolylene-2, 6-diisocyanate)] (poly-urea) and its halogenation and acidification, series 3. 


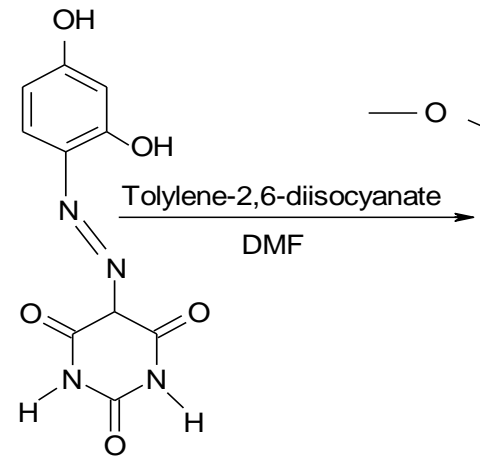

(24)<smiles>[Y10]O[Na]</smiles><smiles>[X]N1C(=O)N([X])C(=O)C([Y])(NN=C2CCCCC2C)C1=O</smiles>

(29)

Scheme 11. Preparation of poly[(1,3-dihydroxy-4(5-azobarbituric acid)-benzene)-co(tolylene-2,6-diisocyanate)] (polyurethane) and its halogenation and acidification, series 5 . 
Table 1

Amounts of polymers and sodium hydroxide used in the preparation of the $\mathrm{N}$ halamine polymers and the final yields

\begin{tabular}{|l|l|l|l|}
\hline Product. & \multicolumn{1}{|c|}{$\begin{array}{c}\text { Reactant }(\text { weight, } \\
\text { quantity). }\end{array}$} & $\begin{array}{c}\text { Sodium hydroxide } \\
(\mathrm{g})\end{array}$ & Final yield \\
\hline $\mathbf{3}$ (chlorinated) & $\mathbf{2}(1.96 \mathrm{~g}, 0.01 \mathrm{~mol})$ & $1.6(0.04 \mathrm{~mol})$ & $2.0 \mathrm{~g}(67 \%)$ \\
\hline $\mathbf{4}$ (brominated) & $\mathbf{2}(1.96 \mathrm{~g}, 0.01 \mathrm{~mol})$ & $1.6(0.04 \mathrm{~mol})$ & $2.7 \mathrm{~g}(63 \%)$ \\
\hline $\mathbf{5}$ (iodinated) & $\mathbf{2}(1.96 \mathrm{~g}, 0.01 \mathrm{~mol})$ & $1.6(0.04 \mathrm{~mol})$ & $3.1 \mathrm{~g}(54 \%)$ \\
\hline $\mathbf{8}$ (chlorinated) & $\mathbf{7}(1.97 \mathrm{~g}, 0.01 \mathrm{~mol})$ & $1.6(0.04 \mathrm{~mol})$ & $1.5 \mathrm{~g}(44 \%)$ \\
\hline $\mathbf{9}$ (brominated) & $\mathbf{7}(1.97 \mathrm{~g}, 0.01 \mathrm{~mol})$ & $1.6(0.04 \mathrm{~mol})$ & $2.0 \mathrm{~g}(39 \%)$ \\
\hline $\mathbf{1 0}$ (iodinated) & $\mathbf{7}(1.97 \mathrm{~g}, 0.01 \mathrm{~mol})$ & $1.6(0.04 \mathrm{~mol})$ & $2.5 \mathrm{~g}(36 \%)$ \\
\hline $\mathbf{1 5}$ (chlorinated) & $\mathbf{1 4}(0.44 \mathrm{~g}, 0.001 \mathrm{~mol})$ & $0.28(0.007 \mathrm{~mol})$ & $0.5 \mathrm{~g}(74 \%)$ \\
\hline $\mathbf{1 6}$ (brominated) & $\mathbf{1 4}(0.44 \mathrm{~g}, 0.001 \mathrm{~mol})$ & $0.28(0.007 \mathrm{~mol})$ & $0.6 \mathrm{~g}(61 \%)$ \\
\hline $\mathbf{1 7}$ (iodinated) & $\mathbf{1 4}(0.44 \mathrm{~g}, 0.001 \mathrm{~mol})$ & $0.28(0.007 \mathrm{~mol})$ & $0.8 \mathrm{~g}(62 \%)$ \\
\hline $\mathbf{2 0}$ (chlorinated) & $\mathbf{1 9}(0.44 \mathrm{~g}, 0.001 \mathrm{~mol})$ & $0.28(0.007 \mathrm{~mol})$ & $0.6 \mathrm{~g}(89 \%)$ \\
\hline $\mathbf{2 1}$ (brominated) & $\mathbf{1 9}(0.44 \mathrm{~g}, 0.001 \mathrm{~mol})$ & $0.28(0.007 \mathrm{~mol})$ & $0.7 \mathrm{~g}(71 \%)$ \\
\hline $\mathbf{2 2}$ (iodinated) & $\mathbf{1 9}(0.44 \mathrm{~g}, 0.001 \mathrm{~mol})$ & $0.28(0.007 \mathrm{~mol})$ & $0.9 \mathrm{~g}(70 \%)$ \\
\hline $\mathbf{2 6}$ (chlorinated) & $\mathbf{2 5}(0.44 \mathrm{~g}, 0.001 \mathrm{~mol})$ & $0.20(0.005 \mathrm{~mol})$ & $0.4 \mathrm{~g}(66 \%)$ \\
\hline $\mathbf{2 7}$ (brominated) & $\mathbf{2 5}(0.44 \mathrm{~g}, 0.001 \mathrm{~mol})$ & $0.20(0.005 \mathrm{~mol})$ & $0.6 \mathrm{~g}(67 \%)$ \\
\hline $\mathbf{2 8}$ (iodinated) & $\mathbf{2 5}(0.44 \mathrm{~g}, 0.001 \mathrm{~mol})$ & $0.20(0.005 \mathrm{~mol})$ & $0.7 \mathrm{~g}(64 \%)$ \\
\hline $\mathbf{3 1}$ (chlorinated) & $\mathbf{3 0}(0.44 \mathrm{~g}, 0.001 \mathrm{~mol})$ & $0.20(0.005 \mathrm{~mol})$ & $0.5 \mathrm{~g} \mathrm{(82 \% )}$ \\
\hline $\mathbf{3 2}$ (brominated) & $\mathbf{3 0}(0.44 \mathrm{~g}, 0.001 \mathrm{~mol})$ & $0.20(0.005 \mathrm{~mol})$ & $0.7 \mathrm{~g} \mathrm{(78 \% )}$ \\
\hline $\mathbf{3 3}$ (iodinated) & $\mathbf{3 0}(0.44 \mathrm{~g}, 0.001 \mathrm{~mol})$ & $0.20(0.005 \mathrm{~mol})$ & $0.8 \mathrm{~g}(73 \%)$ \\
\hline
\end{tabular}


Table 2

IR characterization and halogen content of $\mathrm{N}$-halamine polymers.

\begin{tabular}{|l|c|c|c|}
\hline \multicolumn{1}{|c|}{ Polymer } & Bond & $v_{\max }\left(\mathrm{cm}^{-1}\right)$ & $\begin{array}{c}\text { Halogen } \\
\text { content }(\mathrm{ppm})\end{array}$ \\
\hline $\mathbf{3}$ (chlorinated) & $\mathrm{N}-\mathrm{Cl}$ & 593 & $101 \pm 12$ \\
\hline $\mathbf{4}$ (brominated) & $\mathrm{N}-\mathrm{Br}$ & 688 & $114 \pm 18$ \\
\hline $\mathbf{5}$ (iodinated) & $\mathrm{N}-\mathrm{I}$ & 802 & $116 \pm 22$ \\
\hline $\mathbf{8}$ (chlorinated) & $\mathrm{N}-\mathrm{Cl}$ & 784 & $40 \pm 16$ \\
\hline $\mathbf{9}$ (brominated) & $\mathrm{N}-\mathrm{Br}$ & 680 & $68 \pm 15$ \\
\hline $\mathbf{1 0}$ (iodinated) & $\mathrm{N}-\mathrm{I}$ & 583 & $93 \pm 32$ \\
\hline $\mathbf{1 5}$ (chlorinated) & $\mathrm{N}-\mathrm{Cl}$ & 763 & $190 \pm 11$ \\
\hline $\mathbf{1 6}$ (brominated) & $\mathrm{N}-\mathrm{Br}$ & 618 & $198 \pm 10$ \\
\hline $\mathbf{1 7}$ (iodinated) & $\mathrm{N}-\mathrm{I}$ & 777 & $201 \pm 26$ \\
\hline $\mathbf{2 0}$ (chlorinated) & $\mathrm{N}-\mathrm{Cl}$ & 619 & $187 \pm 14$ \\
\hline $\mathbf{2 1}$ (brominated) & $\mathrm{N}-\mathrm{Br}$ & 618 & $191 \pm 12$ \\
\hline $\mathbf{2 2}$ (iodinated) & $\mathrm{N}-\mathrm{I}$ & 689 & $206 \pm 20$ \\
\hline $\mathbf{2 6}$ (chlorinated) & $\mathrm{N}-\mathrm{Cl}$ & 600 & $160 \pm 17$ \\
\hline $\mathbf{2 7}$ (brominated) & $\mathrm{N}-\mathrm{Br}$ & 712 & $178 \pm 22$ \\
\hline $\mathbf{2 8}$ (iodinated) & $\mathrm{N}-\mathrm{I}$ & 789 & $193 \pm 30$ \\
\hline $\mathbf{3 1}$ (chlorinated) & $\mathrm{N}-\mathrm{Cl}$ & 634 & $176 \pm 11$ \\
\hline $\mathbf{3 2}$ (brominated) & $\mathrm{N}-\mathrm{Br}$ & 683 & $183 \pm 25$ \\
\hline $\mathbf{3 3}$ (iodinated) & $\mathrm{N}-\mathrm{I}$ & 722 & $197 \pm 23$ \\
\hline
\end{tabular}


Table 3

Amounts of polymers and $\mathrm{HCl}$ used in the preparation of poly-quats and the final yields

\begin{tabular}{|c|c|c|c|}
\hline Product. & $\begin{array}{c}\text { reactant (weight, } \\
\text { quantity })\end{array}$ & 1M HCl quantity & Final yield \\
\hline $\mathbf{6}$ & $\mathbf{2}(1.96 \mathrm{~g}, 0.01 \mathrm{~mol})$ & $30.1 \mathrm{ml}$ & $2.1 \mathrm{~g}(70 \%)$ \\
\hline $\mathbf{1 1}$ & $\mathbf{7}(1.97 \mathrm{~g}, 0.01 \mathrm{~mol})$ & $30.1 \mathrm{ml}$ & $2.0 \mathrm{~g} \mathrm{(70 \% )}$ \\
\hline $\mathbf{1 8}$ & $\mathbf{1 4}(0.44 \mathrm{~g}, 0.001 \mathrm{~mol})$ & $6.30 \mathrm{ml}$ & $0.5 \mathrm{~g}(83 \%)$ \\
\hline $\mathbf{2 3}$ & $\mathbf{1 9}(0.44 \mathrm{~g}, 0.001 \mathrm{~mol})$ & $6.30 \mathrm{ml}$ & $0.4 \mathrm{~g}(67 \%)$ \\
\hline $\mathbf{2 9}$ & $\mathbf{2 5}(0.44 \mathrm{~g}, 0.001 \mathrm{~mol})$ & $4.90 \mathrm{ml}$ & $0.5 \mathrm{~g}(74 \%)$ \\
\hline $\mathbf{3 4}$ & $\mathbf{3 0}(0.44 \mathrm{~g}, 0.001 \mathrm{~mol})$ & $4.90 \mathrm{ml}$ & $0.5 \mathrm{~g} \mathrm{(74 \% )}$ \\
\hline
\end{tabular}


Table 4

Inhibition zones diameters $(\mathrm{mm})$ around different polymers on agar plates containing Gram-negative bacteria

\begin{tabular}{|c|c|c|c|c|c|c|}
\hline & series 1 & series 2 & series 3 & series 4 & series 5 & series 6 \\
\hline Control & 0 & 0 & 0 & 0 & 0 & 0 \\
\hline Chlorinated & $7 \pm 1$ & 0 & $18 \pm 1$ & $29 \pm 0$ & $24 \pm 1$ & $28 \pm 1$ \\
\hline Brominated & $18 \pm 1$ & $8 \pm 1$ & $22 \pm 0$ & $27 \pm 1$ & $22 \pm 0$ & $29 \pm 0$ \\
\hline Iodinated & $9 \pm 1$ & $6 \pm 1$ & $15 \pm 1$ & $15 \pm 0$ & $18 \pm 1$ & $10 \pm 1$ \\
\hline Poly-quats & $15 \pm 2$ & $8 \pm 0$ & $6 \pm 1$ & $13 \pm 1$ & $16 \pm 1$ & $13 \pm 1$ \\
\hline
\end{tabular}


Table 5

Inhibition zones diameters $(\mathrm{mm})$ around different polymers on agar plates containing Gram-positive bacteria

\begin{tabular}{|c|c|c|c|c|c|c|}
\hline & series 1 & series 2 & series 3 & series 4 & series 5 & series 6 \\
\hline Control & 0 & 0 & 0 & 0 & 0 & 0 \\
\hline Chlorinated & $6 \pm 1$ & 0 & $19 \pm 1$ & $23 \pm 1$ & $28 \pm 1$ & $28 \pm 0$ \\
\hline Brominated & $14 \pm 1$ & $10 \pm 0$ & $20 \pm 1$ & $21 \pm 1$ & $24 \pm 1$ & $25 \pm 1$ \\
\hline Iodinated & $9 \pm 0$ & $8 \pm 1$ & $18 \pm 1$ & $31 \pm 2$ & $19 \pm 1$ & $20 \pm 1$ \\
\hline Poly-quats & $15 \pm 1$ & $8 \pm 1$ & $7 \pm 0$ & $11 \pm 1$ & $21 \pm 1$ & $19 \pm 1$ \\
\hline
\end{tabular}


Table 6

The inhibition zones $(\mathrm{mm})$ resulted from the dissolved control polymers and monomers

\begin{tabular}{|c|c|c|}
\hline Compound no. & E. coli & S. aureus \\
\hline DMSO (control) & $5 \pm 0$ & $5 \pm 0$ \\
\hline 2 (series 1 control) & $9 \pm 1$ & $7 \pm 1$ \\
\hline 7(series 2 control) & $8 \pm 1$ & $9 \pm 1$ \\
\hline 13 (monomer) & $8 \pm 1$ & $6 \pm 1$ \\
\hline 14 (series 3 control) & $9 \pm 0$ & $9 \pm 1$ \\
\hline 19 (series 4 control) & $10 \pm 1$ & $9 \pm 1$ \\
\hline 24 (monomer) & $9 \pm 1$ & $8 \pm 1$ \\
\hline 25 (series 5 control) & $10 \pm 1$ & $8 \pm 1$ \\
\hline 30 (series 6 control) & $10 \pm 1$ & $7 \pm 1$ \\
\hline
\end{tabular}

